\title{
DIFFERENCE OF HEAT SHOCK PROTEIN 70 SERUM LEVEL BETWEEN PRIMARY ANGLE CLOSURE GLAUCOMA AND OPEN ANGLE GLAUCOMA PATIENTS: INDONESIA SINGLE CENTER EXPERIENCE
}

\author{
Mohamad Nurdin Zuhri ${ }^{1,2}$, Nurwasis Nurwasis ${ }^{1,2}$, Endang Retnowati ${ }^{2,3}$, Windhu Purnomo \\ ${ }^{1}$ Department of Ophthalmology, Dr. Soetomo General Academic Hospital, Surabaya, Indonesia \\ ${ }^{2}$ Faculty of Medicine, Universitas Airlangga, Surabaya, Indonesia \\ ${ }^{3}$ Department of Clinical Pathology, Dr. Soetomo General Academic Hospital, Surabaya, Indonesia \\ ${ }^{3}$ Faculty of Public Health, Universitas Airlangga, Surabaya, Indonesia
}

\begin{abstract}
This study aimed to analyze the differences in Hsp 70 serum levels in patients with primary angle-closure compared to patients with open-angle glaucoma at Dr. Soetomo General Academic Hospital, Surabaya, East Java. This cross-sectional study was conducted on 41 subjects divided into 2 groups consisting of 21 patients with primary angle-closure glaucoma and 20 patients with open-angle glaucoma. Anterior segment examination was assessed by slit-lamp biomicroscope examination. Intraocular pressure on both eyes was measured by Perkin's tonometry. Posterior segment examination was performed with $78 D$ lens and anterior chamber angle was assessed by goniolens. The serum level of Hsp 70 was assessed using a human Hsp 70 sandwich ELISA kit. The data were statistically analyzed with the Mann-Whitney test. The mean serum levels of Hsp 70 in the primary angle-closure group was $5.55 \square 4.75 \mathrm{ng} / \mathrm{ml}$, while the open-angle group was $3.62 \square 2.39 \mathrm{ng} / \mathrm{ml}(\mathrm{p}=0.134)$. There was no difference in Hsp 70 serum levels between the two groups, although the trend obtained serum levels of Hsp 70 patients with primary angle-closure was higher compared to patients with open-angle.
\end{abstract}

Keywords: ELISA; Hsp70; open-angle glaucoma; primary angle closure glaucoma; serum; disease

\begin{abstract}
ABSTRAK
Penelitian ini bertujuan untuk mengevaluasi perbedaan kadar Hsp 70 serum pada pasien dengan glaukoma sudut tertutup primer dan pasien dengan glaukoma sudut terbuka di Rumah Sakit Dr. Soetomo, Surabaya, Jawa Timur. Penelitian crosssectional ini dilakukan pada 41 pasien yang dibagi ke dalam dua kelompok yang terdiri atas 21 pasien dengan glaukoma sudut tertutup primer dan 20 pasien dengan glaukoma sudut terbuka. Pemeriksaan bilik mata depan dilakukan dengan pemeriksaan mikroskop slit lamp. Evaluasi sudut bilik mata anterior dievaluasi dengan menggunakan gonioskopi. Pemeriksaan kadar Hsp 70 serum pada pasien dilakukan dengan menggunakan teknik ELISA dengan kit sandwich ELISA Hsp 70 Human. Analisis statistik dilakukan dengan metode uji Mann-Whitney. Penelitian ini menemukan bahwa rata-rata kadar Hsp 70 serum pada pasien dengan glaukoma sudut tertutup primer sebesar $5.55 \square 4.75 \mathrm{ng} / \mathrm{ml}$ dan pada pasien dengan glaukoma sudut terbuka sebesar $3.62 \square 2.39 \mathrm{ng} / \mathrm{ml}(p=0.134)$. Pada penelitian ini, tidak terdapat perbedaan signifikan antara kadar Hsp 70 serum pada pasien dengan glaukoma sudut tertutup primer dibandingkan dengan pasien dengan glaukoma sudut terbuka, namun terdapat kecenderungan kadar Hsp 70 yang lebih tinggi pada pasien dengan glaukoma sudut tertutup primer dibandingkan pasien dengan glaukoma sudut terbuka.
\end{abstract}

Kata kunci: ELISA; glaukoma sudut tertutup primer; glaukoma sudut terbuka; Hsp70; serum; disease

Correspondence: Nurwasis, Faculty of Medicine, Universitas Airlangga, Surabaya, Indonesia/Department of Ophthalmology, Dr. Soetomo General Academic Hospital, Surabaya, East Java $60286 . \quad$ Email: nurwasis78@gmail.com

pISSN:2355-8393 • eISSN: 2599-056x • doi: 10.20473/fmi.v57i3.23601

- Fol Med Indones. 2021;57:205-209 • Submitted 02 Dec 2020 • Received 29 Mar 2021 • Accepted 17 May 2021

- Open access under CC-BY-NC-SA license • Available at https://e-journal.unair.ac.id/FMI/ 


\section{INTRODUCTION}

Glaucoma is a group of diseases that has the characteristics of optic neuropathy associated with visual field disorders. Although increased intraocular pressure (IOP) is a significant risk factor, its presence does not play a role in the definition of the disease. Optic neuropathy that occurs in glaucoma is caused by apoptosis of retina ganglion cells in optic nerve papilla (ONP) or retinal ganglion cells (RGC). Retinal damages tend to be irreversible and eventually cause a progressive loss of visual field accompanied by decreased visual contrast and color sensitivity. Glaucoma is classified as a hidden disease (silent disease), because the patients often visit physician without any complaints and symptoms until late stage of glaucoma (Ayub et al 2010).

Glaucoma is a disease that causes irreversible blindness in the world and placed the second rank in a prevalence among eye disorders. World Health Organization (WHO) states that $90 \%$ of glaucoma cases in developing countries were not detected, and even in the developed countries, more than $50 \%$ of glaucoma patients were undetected. According to the United Nations, an estimated 60.5 million populations with open and closed-angle glaucoma in 2010 were predicted to increase to 79.6 million in 2020 .

Primary closed-angle glaucoma has recently occurred more frequently than previously estimated. From the approximately 67 million patients with glaucoma in worldwide, an estimated half of patients suffered from primary closed-angle glaucoma, is a common form of glaucoma and is the leading cause of bilateral blindness. Primary closed-angle glaucoma is the main form of glaucoma in East Asia (Chan et al 2016), and is responsible for $91 \%$ of bilateral blindness in China suffered by 1.5 million Chinese people (Zhang et al 2014, Ahram et al 2015).

Optics neuropathy and RGC apoptosis are signs of glaucoma which often associated with structural damage to the ONP. The increased IOP is a known risk factor for glaucoma, along with increasing age, race, and correction of refraction. In addition to IOP, other factors thought to cause glaucoma are vascular, immunological, and neurotoxic factors. Theory-based on immunological factors states, that mechanical stress due to increased IOP, ischemia, excessive release of amino acids, and TNF- $\alpha$ release will increase stress on ONP. Another mechanism that also arises in response to stress is the mobilization of specific cellular proteins called heat shock proteins (Hsp) (Dvoriantchikova et al 2014, Tse et al 2018).
One of the most common Hsp in the eye is Hsp 70. Hsp 70 is a chaperone molecule that has the function of correct refolding of proteins that are dysfunctional and prevents protein aggregation. This mechanism is essential for the RGC defense. Hsp 70 is a critical modulator that plays a role in the immune system in RGC and glial cells and is an integral part of neurodegeneration in glaucoma.

Hsp 70 has a neuroprotective role at high levels, to increase levels of Hsp can be done by giving stress to cells, genetic modification. If Hsp 70 can be induced without stress or genetic modification, high levels of Hsp can be used as a therapy for nerve damage. Geldanamycin, geranylgeranylacetone, and blueberries have neuroprotective properties and increase levels of Hsp 70 (Ayub et al 2010). Ayub et al (2010) investigated the relationship between glaucoma and Hsp 70 levels in peripheral blood in Pakistan showed that the Hsp 70 polymorphism gene was associated with closedangle glaucoma but not in open-angle glaucoma patients (Ayub et al 2010).

Hsp 70 is one of the most widely studied proteins in medicine, yet it has not been much studied in ophthalmology, especially in glaucoma. Therefore, the current study analyzed Hsp 70 changes associated with glaucoma to better understand the pathogenesis of glaucoma and might provide information for developing novel treatment strategies, such as direct neuroprotection and stimulation of regeneration from ONP and RGC.

\section{MATERIALS AND METHODS}

This study was a cross-sectional analytic study conducted by enrolling primary angle-closure glaucoma patients and open angle glaucoma patients in the Policlinic of the Ophthalmology Department, Emergency Treatment Unit, and Jasmine Room ward at Dr. Soetomo General Academic Hospital, Surabaya, East Java from March 2013 to August 2013. Subject inclusion criteria were patients with minimum age of 40-years old and had given their informed consent for participating in this study with some exclusion criteria, namely systemic infections, fever, hypertension, diabetes mellitus, prior ocular surgery, and external ocular infection.

The sampling method was conducted through consecutive sampling method. Anterior eye chamber examination was performed by slit lamp examination, while the posterior eye chamber examination was assessed using $78 \mathrm{D}$ lens. Anterior chamber angle was evaluated through gonioscopy, and IOP was measured 
by Perkin's tonometry. The evaluation of Hsp 70 serum levels was performed by collecting peripheral venous blood and measured by using human Hsp 70 ELISA sandwich kit. Hsp 70 ELISA measurement was conducted at the Department of Clinical Pathology, Dr. Soetomo General Academic Hospital, Surabaya, East Java. Statistical analysis was conducted through MannWhitney test.

\section{RESULTS}

The subjects that were enrolled in this study included 21 patients with primary closed-angle glaucoma and 20 patients with open-angle glaucoma. The largest age group in the primary closed-angle group was 55-59 years old (33\%), with 42 years old as the youngest patient and 66 years old as the oldest patient with a mean patients age of $56 \square 6.49$ years. In the open-angle group, the highest prevalence age group was 40-44 years old (45\%), with 40 years old as the youngest patient and 71 years as the oldest patient, so that the mean patient age was $46.55 \square 6.97$ years. In the patients with primer angle-closure glaucoma, the female patient was more prevalent $(80.95 \%)$, while the male was $19.05 \%$. On the other hand, patients with open-angle glaucoma showed an equal distribution of male and female ratio prevalence. Therefore, there were no hypertensive subjects with fever that were recorded in this study.

Table 1. Subject distribution based on IOP

\begin{tabular}{cllccccc}
\hline & \multicolumn{5}{c}{ IOP (mmHg) } \\
\cline { 3 - 6 } & Minimum & Maximum & Mean & $\begin{array}{c}\text { Std. } \\
\text { Deviation }\end{array}$ & $p$ \\
\hline \multirow{2}{*}{ R-IOP } & Closed angle & 10 & 50 & 28.57 & 13.08 & \multirow{2}{*}{$<0.001^{\mathrm{a}}$} \\
\cline { 2 - 6 } & Open angle & 10 & 20 & 14.95 & 2.31 & \\
\hline \multirow{2}{*}{ L-IOP } & Closed angle & 12 & 50 & 28.81 & 14.52 & \multirow{2}{*}{$0.001^{\mathrm{a}}$} \\
\cline { 2 - 6 } & Open angle & 10 & 20 & 15.25 & 2.47 & \\
\hline
\end{tabular}

Abbreviations: R-IOP: Right Intra Ocular Pressure; L-IOP: Left Intra Ocular Pressure. ${ }^{\alpha}$ Analyzed using Mann-Whitney Test

In this study, patients with primary closed-angle glaucoma had a minimum body temperature of $36.5^{\circ} \mathrm{C}$, and maximum of $37.3^{\circ} \mathrm{C}$ with an average of $36.95 \pm 0.22$ ${ }^{\circ} \mathrm{C}$. Meanwhile, patients with open-angle glaucoma patients had a minimum body temperature of $36.7^{\circ} \mathrm{C}$ and a maximum of $37.3^{\circ} \mathrm{C}$, with average body temperature of $36.98 \pm 0.18{ }^{\circ} \mathrm{C}$.

Primary closed-angle glaucoma patients exhibit a higher IOP compared to open-angle glaucoma patients with the mean of $28.57 \mathrm{mmHg}$ for right eye and 28.81 for the left eye. On the open-angle glaucoma patients, there were recorded $14.95 \mathrm{mmHg}$ right eye $\mathrm{IOP}$, and $15.25 \mathrm{mmHg}$ left eye IOP (Table 1).

Table 2. Subject distribution based on blood sugar

\begin{tabular}{lccccc}
\hline & \multicolumn{5}{c}{ Blood Sugar (mg/dl) } \\
\cline { 2 - 5 } & Min. & Max. & Mean & $\begin{array}{l}\text { Std. } \\
\text { Deviation }\end{array}$ & $p$ \\
\hline $\begin{array}{l}\text { Primary } \\
\text { closed-angle }\end{array}$ & 70 & 134 & 98.38 & 15.74 & $0.835^{\mathrm{a}}$ \\
\hline Open-angle & 68 & 176 & 102.05 & 27.57 & \\
\hline
\end{tabular}

${ }^{\alpha}$ Analyzed using Mann-Whitney Test
Primary closed-angle glaucoma patients had a mean of random blood sugar level of $93.38 \pm 15.74 \mathrm{mg} / \mathrm{dl}$, whereas Open-angle glaucoma patients had a mean random blood sugar level of $102.05 \pm 27.57 \mathrm{mg} / \mathrm{dl}$ (Table 2).

Table 3. Subject distribution based on Hs CRP

\begin{tabular}{lccccc}
\hline & \multicolumn{5}{c}{ Hs CRP (mg/l) } \\
\cline { 2 - 5 } & Min. & Max. & Mean & $\begin{array}{c}\text { Std. } \\
\text { Deviation }\end{array}$ & $p$ \\
\hline $\begin{array}{l}\text { Primary } \\
\text { closed-angle }\end{array}$ & 0.084 & 5.785 & 1.557 & 1.348 & \multirow{2}{*}{$0.754^{\mathrm{a}}$} \\
\hline Open-angle & 0.001 & 7.934 & 1.938 & 2.018 & \\
\hline
\end{tabular}

a Analyzed using Mann-Whitney Test

Primary closed-angle glaucoma patients had a mean of $1.557 \pm 1.348 \mathrm{mg} / \mathrm{l} \mathrm{Hs} \mathrm{CRP}$, and open-angle glaucoma patients had a mean Hs CRP level of $1.938 \pm 2.018 \mathrm{mg} / \mathrm{l}$ (Table 3).

Table 4. Subject distribution based on Hsp 70 level

\begin{tabular}{lccccc}
\hline \multicolumn{5}{c}{ Kadar Hsp70 ng/ml) } \\
\hline & Min. & Max. & Mean & $\begin{array}{c}\text { Std. } \\
\text { Deviation }\end{array}$ & $p$ \\
\hline $\begin{array}{l}\text { Primary } \\
\text { closed-angle }\end{array}$ & 0 & 20.84 & 5.55 & 4.57 & $0.134^{\mathrm{a}}$ \\
\hline
\end{tabular}




\begin{tabular}{lllll}
\hline Open-angle & 0 & 8.28 & 3.62 & 2.39
\end{tabular}

${ }^{\alpha}$ Analyzed using Mann-Whitney Test

Primary closed-angle glaucoma patients had a mean Hsp 70 level of $5.55 \pm 4.57 \mathrm{ng} / \mathrm{ml}$ higher than openangle patients with mean Hsp 70 level of $3.62 \pm 2.39$ $\mathrm{ng} / \mathrm{ml}$. The normality test results showed that the data were not normally distributed, while Mann-Whitney test results obtained $\mathrm{p}=0.134(\mathrm{p}>0.05)$ (Table 4$)$.

\section{DISCUSSION}

This study results suggested an in-line results of primary closed angle glaucoma incidences that mainly occurred at the 55-65 years old patients. The anterior eye chamber tends to decrease in depth and volume according to age and causes pupillary block. Therefore, the prevalence of primary closed-angle glaucoma were increased with aging (Zhang et al 2020). This study also exhibited higher ratio of female primary closed-angle glaucoma patients compared to male which also matched with prior studies. Several studies also suggested that women had an increased risk of primary closed-angle glaucoma. Moreover, they had more superficial anterior eye chamber compared to men (Wright et al 2015).

In this study, we excluded patients with hypertension, because hypertension tend to caused ane be caused by oxidative stress and it tends to induce the expression of Hsp in blood vessel wall smooth muscle cells (Rodriguez-Iturbe \& Johnson 2018). We also excluded patients with fever due to the tendency of increasing in Hsp 70 levels which was induced by various stressors, including the increase of body temperature. The increase of Hsp 70 was caused by the protein degradation that occured in patients with fever, which needed chaperone to protect from extensive protein denaturation. Hsp 70 is one of the chaperone protein that facilitates protein refolding and protect from protein denaturation. It is also reported that Hsp 70 levels also increased in response to heat exposure (Singh \& Hasday 2013).

In animal studies, it was found that Hsp 70 is a protein that is easily affected by heat, and its expression can increase after fever in rat lungs, liver, kidneys, and retina of mice as well as in rabbit cerebellum. In vitro evaluation and in vivo induction of Hsp 70 by fever in human leukocytes through flow cytometry and Hsp 70 blood level measurement suggested that Hsp 70 expression depended on temperature and cell type (different in neutrophil, lymphocyte, and monocyte). The systemic increase in body temperature triggered by fever stimulated the expression of Hsp 70 in peripheral leukocytes, especially in monocytes. Fever that induced Hsp 70 expression could protect monocytes when confronted with cytotoxic inflammatory mediators, thereby being able to improve the course of the disease (El-Radhi 2012).

Animal studies on the mechanisms involving ischemia in the retina were carried out with a variety of treatments. Liu and Prokosch (2021) showed that an increase in IOP could cause retinal ischemia. Joachim et al (2011) increased IOP to $130 \mathrm{mmHg}$ for 1 hour to study the antibody response to ischemia (Joachim et al 2011). Windisch et al (2009) in animal studies also reported an increased Hsp expression in RGC after an increase in IOP of $100-110 \mathrm{mmHg}$ for 30 or 90 minutes. In this study, we observed an average IOP of 28.81 $\mathrm{mmHg}$ and there was a notable difference compared to IOP in experimental animals' models which might suggest that study about hsp70 level changes should be conducted as a continuous evaluation or a cohort to more precisely monitor changes in Hsp expression. Moreover, chronic and progressive process is the main mechanism of glaucoma in humans and the animal models that were reported tend to be more suitable for mimicking acute glaucoma pathophysiology (Nucci et al 2018). Therefore, it is suggested that the evaluation of acute and chronic glaucoma should be assessed in a distinctive point of view (Windisch et al 2009).

\section{CONCLUSION}

There was a higher Hsp 70 serum level of primary closed-angle glaucoma patients compared to open-angle glaucoma patients, although serum levels of Hsp 70 between two groups was statistically insignificant. It was also suggested that Hsp 70 played a role in glaucoma pathogenesis and immunology mechanism. This mechanism could lead to novel glaucoma management approach by either blocking or promoting Hsp 70. Further studies with a larger and more heterogeneous subjects range was necessary to more objectively strengthen this finding.

\section{REFERENCES}

Ahram DF, Alward WL, Kuehn MH (2015). The genetic mechanisms of primary angle closure glaucoma. Eye 29, 1251-1259.

Ayu H, Khan MI, Micheal S, et al (2010). Association of eNOS and HSP70 gene polymorphisms with glaucoma in Pakistani cohorts. Molecular Vision 16, 18-25. 
Chan EW, Li X, Tham Y-C, et al (2016). Glaucoma in Asia: regional prevalence variationsand future projections. Br J Ophthalmol 100, 78-85.

Dvoriantchikova G, Santos ARC, Saeed AM, et al (2014). Putative role of protein kinase $\mathrm{C}$ in neurotoxic inflammation mediated by extracellular heat shock protein 70 after ischemia-reperfusion. Journal of Neuroinflammation 11, 1-16.

El-Radhi ASM (2012). Fever management: Evidence vs current practice. World Journal of Clinical Pediatrics 1, 29-33.

Joachim SC, Wax MB, Boehm N, et al (2011). Upregulation of antibody response to heat shock proteins and tissue antigens in an ocular ischemia model. Investigative Ophthalmology \& Visual Science 52, 3468-3474

Liu H, Prokosch V (2021). Energy metabolism in the inner retina in health and glaucoma. International Journal of Molecular Sciences 22, 1-19.

Nucci C, Martucci A, Giannini C, et al (2018). Neuroprotective agents in the management of glaucoma. Eye 32, 938-945.

Rodriguez-Iturbe B, Johnson RJ (2018). Heat shock proteins and cardiovascular disease. Physiology International 105, 19-37.
Singh IS, Hasday JD (2013). Fever, hyperthermia and the heat shock response. International Journal of Hyperthermia 29, 423-435.

Tse BC, Dvoriantchikova G, Tao W (2018). Tumor necrosis factor inhibition in the acute management of traumatic optic neuropathy. Investigative ophthalmology \& visual science 59, 2905-2912.

Windisch BK, LeVatte TL, Archibald ML, et al (2009). Induction of heat shock proteins 27 and 72 in retinal ganglion cells after acute pressure-induced ischaemia. Clinical \& experimental ophthalmology 37, 299-307.

Wright C, Tawfik MA, Waisbourd M, et al (2015). Primary angle-closure glaucoma: an update. Acta Ophthalmologica 94, 217-225.

Zhang N, Wang J, Chen B, et al (2020). Prevalence of primary angle closure glaucoma in the last 20 years: A meta-analysis and systematic review. Frontiers in Medicine 7, 1-10.

Zhang Y, Li SZ, Li L, et al (2014). Quantitative Analysis of Iris Changes After Physiologic andPharmacologic Mydriasis in a Rural Chinese Population. Investigative Ophthalmology \& Visual Science 55, 4405-4412. 